\title{
OER as a Tool for Sustainable Development: The Ukrainian - Latvian Experience of Forensic Science Experts
}

\author{
By Karina Palkova ${ }^{1}$, Olena Agapova ${ }^{2}$, Mg.iur. Aelita Zîle ${ }^{3}$
}

\begin{abstract}
One of the important factors influencing the quality of modern education is Open Educational Resources. The new form of education was recognised by UNESCO and become an important element in achieving the main goals of Sustainable Development in the field of Education. Open Educational Resources play transformative role in the cases of supporting both regular and specific fields of education. The paper examines the role of Open Educational Resources in the field of such a specific industry/occupation as forensic experts. Forensic experts' learning process has several levels that start from the access to higher education. The requirements to receive forensic expert's certificate stems from the national law. And these requirements could vary from country to country. Open Educational Resources represent an opportunity for a great number of learners in various study fields. Nevertheless, those resources are not used in forensic expert education. To clarify the possibility to use Open Educational Resources in specific forensic expert education field, a research on forensic expert education in Latvia and Ukraine has been conducted. Open Educational Resources can improve the quality of education on at least two levels. The first one is the quality of teaching content and the second is the modern learning environment, providing access to all necessary researches that are necessary to pass the forensic expert examination. Authors found out that nowadays Open Educational Resources are not applied in forensic experts' education. As the research reveals, the main resources are legal documents and practical knowledge provided by academic staff. From the authors perspective it is suggested to create an Open Educational Resource that could provide forensic experts with the information necessary to pass the examination and to improve both practical and theoretical skills. Nevertheless, Open Educational Resources in such a specific field can met several challenges.
\end{abstract}

Keywords: OER, education, future, forensic experts

\section{Introduction}

The contemporary trend in transferring knowledge is evolving. We witness the dynamic development of higher education, academic and scientific area. The virtual world and the power of the Internet urge to consider new forms and methods of professional training of forensic science personnel. Distancing during the scientific research and educational processes, the use of digitised scientific and educational resources during the training, audio and video recordings, etc., allow you to improve educational methods and break down the barriers in accessing the educational and scientific information.

New technology has changed the view of students, researchers and academia on the educational methods and teaching. Such characteristics as "openness" and "accessibility" 
more than ever before have become the features of the resilience of educational institutions in challenges of our time. The use of new educational models such as Open Educational Resources is a prerequisite for complying with the global information world. Professional training of the students and the researchers who are obtaining a Bachelor's, Master's and Doctor degrees in Forensic Science and Criminalistics in educational institutions is mainly implemented with the use of traditional methods of teaching, particularly, lectures, seminars, field studies, individual learning, etc. There is no doubt that such approach in the training of students has proved itself in the Educational Services Industry, however the formation of new educational practice in the area of training of forensic science personnel will allow us to break down the barriers in accessing the educational materials.

It may be stated that nowadays the study of the issues dedicated to the improvement of educational methods in the area of the professional training of forensic science experts for Ukrainian and Latvian institutions is a topical objective and requires a deep theoretical comprehension to make specific propositions.

\section{Materials and Methods}

The research is based on Latvian and Ukrainian national laws and regulations, as well international policy making documents and international regulations in the field of Open Educational Resources and forensic expert education. The research materials were the results of comparative analyses and forensic expert education field studies both in Latvia and Ukraine. The views of scientists on the above issue were studied and presented. The research analyses scientific information received from national and international level scientific journals applying scientific methods from legal perspective. The main research methods are the systematic approach, analytical and comparative method.

\section{Research}

The UN General Assembly Resolution dated 25 September 2015 №A/70/L.1 "Transforming our World: The 2030 Agenda for Sustainable Development" lays out 17 Sustainable Development Goals (SDGs) and 169 global targets, one of which emphasises to "ensure inclusive and equitable quality education and promote lifelong learning opportunities for all" (Transforming our world: the 2030 Agenda for Sustainable Development, 2015).

In accordance with Declaration of Principles: Building the Information Society: A Global Challenge in the New Millennium dated 12.12.2003 № WSIS-03/GENEVA/DOC/4-E adopted by the World Summit on the Information Society, continuous learning and education for adults, re-training, lifelong learning, distance education and other special services may make a decisive contribution to empowerment of employment and help people to use new prospects which open through information and communication technologies regarding the jobs, self-employment, and mastering new jobs. The necessary foundation for this is awareness and literacy in the area of information and communication technologies. IT developers, publishers, content creators as well as educators, instructors, archivists, librarians, and students, especially in the least developed countries should 
participate in the formation of "information society" (Building the Information Society: a global challenge in the new Millennium, 2003).

There is no doubt that providing the opportunity of access to information, knowledge and ideas for everyone is an essential part of the information society that is open for all.

In 2002, the term “Open Educational Resource" (OER) was first coined at UNESCO's Forum on the Impact of Open Courseware for Higher Education in Developing Countries, sponsored by the William and Flora Hewlett Foundation (Hewlett Foundation). Since then, UNESCO has been promoting the adoption of OER at national and institutional levels with a view to harnessing freely adaptable resources to achieve the Education for All (EFA) Goals. The resulting Paris OER Declaration reaffirmed the shared commitment of international organisations, governments, and institutions to promote the open licensing and free sharing of publicly funded content, the development of national policies and strategies on Open Educational Resource, capacity-building and open research (Wiley, D.A., 2020) .The Open Educational Resource movement has the potential to provide broader access to higher education and to significantly improve the quality of higher education for a diverse body of learners. To date, many Open Educational Resource projects are focused on making content that supports existing traditional forms of instruction openly and freely available. In these projects, the power of the Internet is used for breaking down the barriers to access by serving as a medium for freely distributed content. Making the existing content available in this way is based on the revolutionary idea that education and research are best advanced when knowledge is shared openly (Foreword by the Assistant Director-General for Education, UNESCO, 2016). These efforts change the Internet as an educational resource in several ways and increase the mumber and diversity of quality educational resources that can be found (Atkins, Brown \& Hammond, 2007).

In most countries, applying EdTech has become an essential part of the learning process. EdTech is an attribute of Globalisation, a factor of competitiveness of educational services which have an impact on the development of democracy in the context of the information society.

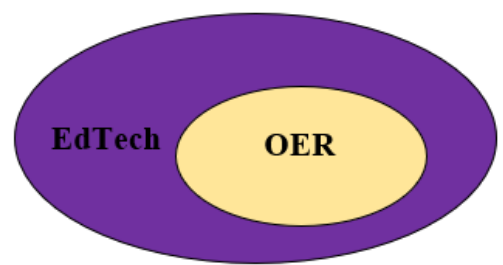

Figure 1.

We support the views of Diana G. Oblinger and Marilyn M. Lombardi on the current state of implementation of educational technologies. The scientists emphasise that the developing countries are pinning their hopes for economic advancement on building skilled workforce, which means that postsecondary education is quickly becoming an imperative for vast segments of the world's population. For these areas of the world, where the existing infrastructure cannot keep up with exploding demand, the open access to educational resources using online technologies may provide a solution. Nevertheless, the notion of universal access to free educational resources faces inherent tensions from within 
the academy, where the barriers to adoption have more to do with tradition and attitude than technology (Toru Iiyoshi, Vijay Kumar M. S., Brown J. S., 2008). McSherry considers that institutional reward systems and intellectual property alone pose significant challenges to the resource sharing principles that underlie open education (McSherry, 2001).

The philosophy of Open eEducational resources is that of making educational materials a common or public good from which all and everyone, in theory, can benefit, but most especially those who receive the least benefit from current systems of the provision of education, whether publicly or privately funded (Geser, 2006). However, this noble philosophy is constrained in practice by two major overlapping dimensions: (1) the degrees of openness presented by Open Educational resources in relation to the context in which someone lives and works, and (2) the degrees of freedom presented to that person by the nature of the Open Educational resources, whatever that person's context (Toru Iiyoshi, Vijay Kumar M. S., Brown J. S., 2008).

Altogether there are over 2000 freely available university courses currently online, and more OER projects are emerging at universities in Australia, Brazil, Canada, Hungary, India, Iran, Ireland, the Netherlands, Portugal, Russia, South Africa, Spain, Thailand, the UK, the US, and Vietnam (David Wiley. Organisation for Economic Co-operation and Development Centre for Educational Research and Innovation Expert Meeting on Open Educational Resources, 2002). The most well-known resource is: OER Commons (OER Commons, 2021) etc.

It is worthwhile to note that the practice of the implementation of highly specialised and thematic Open Educational Resources in Latvia and Ukraine is at an early stage of development. The overwhelming majority of the resources are presented as digital repositories, digital libraries, open access journals, collections of scientific papers, etc. The Open Educational Recourse that would be dedicated to the issues of Forensic Science and Criminalistics only has not been created yet.

It should be noted that Open Educational Resources in such a specific field as Forensic Science can provide a rich and flexible learning environment. This environment can be the basic to gain knowledge, as well as acquire skills among young professionals and current students in the Criminalistics field. Nevertheless, among advantages of those resources several problematic issues can be identified. Open Educational Resources provide open access information and nowadays have a greater impact on both teaching and learning. However, the content of such resources can lead to discussions from the security perspective (Sandanayake, T.C., Karunanayaka, S.P. \& Madurapperuma, A.P., 2021).

The following Open Educational Recourses of Ukraine should be mentioned: Prometheus project (Prometheus project, 2020) - free online courses for teachers; institutional repositories of Ukrainian universities, for instance, Electronic Kyiv-Mohyla Academy Institutional Repository (Electronic Kyiv-Mohyla Academy Institutional Repository, 2021), or, the ELARTU (ELARTU, 2021) educational resource.

Initiation of the creation of Digital Educational Resources has normative-legal foundation. At the legislative level, Ukraine has established the necessity of the implementation of information and communication technologies in various spheres of activities of the State and the creation of new resources, methods, instruments and technologies on their basis. The Law of Ukraine dated 05 May 2017 № 2145-VIII “On Education” guarantees the right of access to public educational, scientific and information resources, including the Internet, electronic textbooks and other multimedia resources in accordance with the 
procedure established by law (On education. Law of Ukraine, 2017).

Strategic issues of the development of the information society, fundamental and applied scientific research as well as science-intensive technologies, innovative development of the national programming industry, information and communication technology production infrastructure are defined by the Order of the Cabinet of Ministers of Ukraine dated 15 May 2013 № 386-p “On the Strategy of Information Society Development in Ukraine” (Pro skhvalennia Stratehii rozvytku informatsiinoho suspilstva v Ukraini, 2013).

To create these conditions in Ukraine the following ideas are proposed: 1) to stimulate the development of scientific and scientific-technical research by introducing the latest information and communication technologies; 2) to accelerate the development of the national system of digital scientific and technical information ensuring the creation of digital resources and electronic databases of scientific and scientific-technical information; 3 ) to provide access to foreign digital resources and electronic databases of scientific and scientific-technical information; 4) to stimulate the development of the Ukrainian segment of scientific cooperation networks and research teams; 5) to provide public-private support in the implementation of projects aimed at creating electronic scientific resources with open access (Rozporiadzhennia Kabinetu Ministriv Ukrainy, 2013).

Among the laws and regulations that define the notion of the Digital Educational Recourse (hereafter - DER), their main types, requirements, the procedure of development and implementation there is the Order of the Ministry of Education and Science, Youth and Sports of Ukraine dated 01 October 2012 № 1060 "On Approval of the Regulations on Electronic Educational Resources” (Rozporiadzhennia Kabinetu Ministriv Ukrainy, 2013). DERs mean teaching tools on digital media of any type or placed in information and telecommunication systems, which are reproduced by electronic means and used in the educational process. DERs are created in order to ensure the modernisation of the educational process, the content of the educational space, to provide equal access for participants in the educational process regardless of their place of residence and form of education in accordance with quality educational and methodological materials created on the basis of information and communication technologies (Rozporiadzhennia Kabinetu Ministriv Ukrainy, 2012).

Training and internship of professionals who intend to obtain or confirm the qualification of a forensic expert is regulated by the Order of the Ministry of Justice of Ukraine dated 03 March 2015 №301/5 “On Approval of the Regulations on the Central Expert and Qualification Committee under the Ministry of Justice of Ukraine and Certification of Court Experts" (Nakaz Ministerstva yustytsii Ukrainy, 2015).

According to the results of the analysis of regulatory and legal support, we note that the legislation of Ukraine generally guarantees the right to access public educational, scientific, information resources and the use of Digital Educational Resources and Digital Educational Resources with Open Access during the educational process. It is worthwhile to note that the legislation of Ukraine does not contain a normative definition of the Open Education Resource. There are no provisions that would reveal the peculiarities of its use in educational institutions and elsewhere. We believe that the implementation of such a technological solution as creation of Open Educational Resources must be enshrined in law.

The issue of the implementation of Open Educational Resources is properly regulated in Latvia. 
It must be noted that Open Educational Resources in Latvia are in development process. However, Open Educational Resources are not used in the field of forensic experts' education yet. In Latvia the education of forensic experts is regulated by the Law on Forensic Experts (Law on Forensic Experts, 2016). The purpose of the law is to regulate the professional activities of forensic experts in order to ensure an unbiased, judicial and scientifically justified forensic expert-examination in the State (Law on Forensic Experts, 2016). Hence, the Law provides information about what kind of persons are entitled to perform a forensic expert-examination in the Republic of Latvia as well. In Latvia the experts are divided into two groups - forensic experts and private forensic experts. As well as the law provides the information who can be forensic expert candidates and what is the procedure for awarding the certificate.

According to the Law, a forensic expert in Latvia is a person who has special knowledge and experience in a certain field of science, technology, art or craft and who has obtained a forensic expert certificate in accordance with the procedures laid down in this Law. Hence, there are specific requirements for the expert's education (Law on Forensic Experts, 2016). Therefore, the attention should be paid to the quality and modernisation process of particular education model.

It shall be noted, that according to the Latvian law a state forensic expert is a forensic expert whose work duty is to perform forensic expert-examinations in a forensic expertexamination institution, a state institution of direct administration or a state capital company. And important is the fact that a state forensic expert may not act concurrently as a private forensic expert (Law on Forensic Experts, 2016). Nevertheless, a private forensic expert is a state-recognised forensic expert who performs an expert-examination within the framework of his or her economic activity or on the basis of an employment contract with a merchant, and also in associations and foundations (Law on Forensic Experts, 2016). According to the provided regulations, private forensic experts have several restrictions that regulated by law. For instance, a private forensic expert does not have the right to perform a forensic expertexamination of firearms and ammunition thereof, as well as they are not able to perform a forensic expert-examination of explosive devices and explosive substances. Besides, the private experts are not entitled to perform a forensic expert-examination of coins and banknotes and a forensic expert-examination related to narcotic, psychotropic and highly potent substances and action thereof etc. (Law on Forensic Experts, 2016).

To become a forensic expert, an individual must master an accredited study programme corresponding to the specialty chosen in an institution of higher education (academic study programme or second level higher vocational study programme) and of course the individuals must have professional knowledge and experience of the forensic expert, etc. (Law on Forensic Experts, 2016). The specific rules regarding the forensic expert certification are available in Latvia (Procedures for the Certification and Recertification of Forensic Experts, 2016). The rules provide the provisions about the content of examination of forensic experts, the minimum amount of knowledge necessary for the certification of forensic experts, etc. There is a specific training programme that consists of two parts. The first part is more general and determines the legal and general theoretical knowledge of forensic expert-examinations necessary for the forensic expert. And the second part is a special part that determines the academic subjects to be mastered during training in the selected specialty of the expert, the minimum number of expert 
examinations to be carried out mandatorily and the amount and level of practical skills of candidates (Procedures for the Certification and Recertification of Forensic Experts, 2016). The important fact from the educational perspective is the necessity of resources for the expert candidates as well as certificated experts' education. And from our perspective the Open Educational Resource, specifically in the Forensic Science field could be strongly supported to improve the content of the certification requirements, It is worth emphasising that the training of expert personnel in Ukraine and Latvia is carried out according to a similar training scheme.

\begin{tabular}{|c|c|c|c|}
\hline \multirow{2}{*}{\multicolumn{4}{|c|}{$\begin{array}{c}\text { THE PROCESS OF TRAINING OF FORENSIC EXPERT PE } \\
\text { UKRAINE }\end{array}$}} \\
\hline & & & \\
\hline \multirow{2}{*}{\multicolumn{4}{|c|}{$\begin{array}{c}\text { Level } 1 . \\
\text { Obtaining higher education in an educational institution. }\end{array}$}} \\
\hline & & & \\
\hline \multicolumn{4}{|c|}{ Obtaining the second level (Master's degree) of higher education } \\
\hline \multicolumn{4}{|c|}{$\begin{array}{l}\text { Level } 2 . \\
\text { Obtaining an expert specialty in an expert institution (centres, establishments) }\end{array}$} \\
\hline \multicolumn{4}{|c|}{ The process of obtaining the expert specialty consists of two stages: } \\
\hline \multicolumn{2}{|c|}{ Stage 1: Training (internship) of Experts } & \multicolumn{2}{|c|}{ Stage 2: Certification and Examination } \\
\hline $\begin{array}{l}\text { Training programme } \\
\text { in theoretical, } \\
\text { organisational and } \\
\text { procedural issues of } \\
\text { forensic examination } \\
\text { (lectures, seminars, } \\
\text { etc.); }\end{array}$ & $\begin{array}{c}\text { Training programme in relevant } \\
\text { expert specialties }\end{array}$ & $\begin{array}{c}\text { Certification } \\
\text { (qualification } \\
\text { examination) for the } \\
\text { purpose of awarding } \\
\text { and confirming the } \\
\text { qualification of a } \\
\text { forensic expert in the } \\
\text { Central Expert and } \\
\text { Qualification } \\
\text { Committee under the } \\
\text { Ministry of Justice of } \\
\text { Ukraine }\end{array}$ & $\begin{array}{l}\text { Awarding (confirmation) } \\
\text { of the qualification of a } \\
\text { forensic expert. } \\
\text { Issuance of a certificate of } \\
\text { qualification of a forensic } \\
\text { expert in a certain type of } \\
\text { expert specialty. }\end{array}$ \\
\hline \multicolumn{4}{|c|}{ THE PROCESS OF TRAINING OF FORENSIC EXPERT PERSONNEL } \\
\hline \multicolumn{4}{|c|}{ LATVIA } \\
\hline \multicolumn{4}{|c|}{$\begin{array}{c}\text { Level } 1 . \\
\text { Obtaining higher education in an educational institution. }\end{array}$} \\
\hline \multicolumn{4}{|c|}{ Obtaining the second level (Master's degree) of higher education } \\
\hline \multicolumn{4}{|c|}{$\begin{array}{c}\text { Level } 2 . \\
\text { Obtaining an expert specialty in an expert institution }\end{array}$} \\
\hline \multicolumn{4}{|c|}{ The process of obtaining the expert specialty consists of two stages: } \\
\hline \multicolumn{2}{|c|}{ Stage 1: Training (internship) of experts } & \multicolumn{2}{|c|}{ Stage 2: Certification and Examination } \\
\hline $\begin{array}{l}\text { A general part (it } \\
\text { determines the legal } \\
\text { and general theoretical } \\
\text { knowledge of forensic } \\
\text { expert-examinations } \\
\text { necessary for a } \\
\text { forensic expert and is } \\
\text { the same in all } \\
\text { programmes of } \\
\text { specialties); }\end{array}$ & $\begin{array}{l}\text { A special part (it determines the } \\
\text { academic subjects to be } \\
\text { mastered during training in the } \\
\text { selected specialty of the expert, } \\
\text { the minimum number of study } \\
\text { expert-examinations to be } \\
\text { carried out mandatorily, the } \\
\text { number of expert opinions of } \\
\text { study expert-examinations to be } \\
\text { submitted for review } \\
\text { (hereinafter - the opinions), and } \\
\text { degree and level of practical } \\
\text { skills of candidates. }\end{array}$ & $\begin{array}{c}\text { In the first part of the } \\
\text { examination the } \\
\text { candidate provides } \\
\text { written replies to } 60 \\
\text { test questions regarding } \\
\text { the general part of the } \\
\text { training }\end{array}$ & $\begin{array}{l}\text { In the first part of the } \\
\text { examination the candidate } \\
\text { orally provides answers to } \\
\text { three questions specified } \\
\text { in the examination paper } \\
\text { regarding the special part } \\
\text { of the training programme } \\
\text { and defends the reviewed } \\
\text { opinions and qualification } \\
\text { paper. }\end{array}$ \\
\hline
\end{tabular}


Taking into consideration the training process of forensic experts in Ukraine and Latvia, the statistics of forensic experts should be analysed during the research. In accordance with the Register of Forensic Experts that contains information on forensic experts, there are 201 forensic experts in Latvia. The experts are employed in such state institutions as the State Border Guard Forensic Service, State Forensic Science Bureau, State Police Department of Criminalistics and State Revenue Service Customs Laboratory. But, the total number of experts (except private experts) is 285. [Register of Forensic Experts of Latvia, 2021]. While in Ukraine there are 11960 forensic experts in specific forensic disciplines (except private experts) [Ministerstvo Justicii Ukraini, 2021].

Hence, in Latvia, as well as in Ukraine, there is the legal basis for the Register of Forensic Experts, including stipulating that it will contain information on the suspension of a forensic expert's right to work, as well as information about forensic experts' competency. The Registers of Forensic Experts in both countries are public. Both, for instance, in civil cases, as well as criminal cases may require examination of important facts requiring expert's knowledge in science, technology, criminalistics or another field. The publicly available information about the experts gives opportunity to involved parties to invite experts to examine and assess the circumstances of the case. But, nevertheless, the parties have the right to ask the court to invite forensic experts in accordance with the procedures of the particular law, for instance, Civil Procedure Law. In this case, the National Law on Forensic Experts must also be observed. The forensic expert's opinion is playing an increasingly important role in criminal, civil and administrative proceedings since the facts established in the course of forensic investigations are based on unbiased scientific research.

Besides, it must be noted, that with the technological progress the new disciplines of forensic expertise have been developed, for instance, digital forensics experts. In practice, this expertise can be necessary in criminal cases, where the attorney at law is dealing with cases involving Internet services and file-sharing programs. The particular kind of expertise can be used to examine big data, file system metadata, operating system artefacts and other file evidence.

With the increasing usage of information technology, the digital forensic analysis, becomes an important technique to improve examination efficiency (Kumar, G., Saha, R., Lal, C., \& Conti, M. (2021). In the field of information technology in Latvia there are 2 to 5 new requests every week, while around 100 requests are waiting in line.

Therefore, it is obvious that the process of training a future forensic expert covers several stages of training and combines different degrees of difficulty of the training programme. New challenges related to technological progress impact the education of forensic experts and require new and unique skills. Modernisation of the learning process and the use of resources with digitised educational and scientific materials, audio and video recordings, etc., allow you to improve teaching tools, introduce new forms and methods of future experts' training. Considering the specific nature of the forensic expert activity, we believe it is logical that the training of future professionals in this field should be up to date. The use of new distance learning opportunities for students and the creation of open scientific and educational resources will be a good addition to the educational programme of educational institutions and over time will be able to replace some approaches to the training of future forensic experts. 
Within the framework of the Latvian - Ukrainian research project "Open educational resource: forensic examination" it is planned to create an Open Educational Resource for training future personnel of expert institutions of Ukraine and Latvia (Kliuiev, O. ., Agapova, O. ., \& Palkova, K. 2020). As a result of work on the project there will be created an open web resource with scientific, research and other materials, as well as educational video presentations of forensic work during forensic examinations and expert research with the possibility of their remote use by end users (students and graduate students, scientists, forensic experts of Ukraine and Latvia) (Latvian-Ukrainian Joint Program of Scientific and Technological Cooperation Project, 2021).

The spate of criminal activities requires the prompt detection of crimes, while the training of future experts in the conditions of the spread of COVID-19 is limited. The vast majority of Ukrainian and Latvian higher education institutions of legal studies have only separate curricula for students of different courses, dedicated to the study of the basics of Forensic Science. Students, as well as forensic expert candidates use only electronic or printed books, websites, etc. At the same time, the specificity of forensic examination is that it is directly related to the conduct of certain experiments. Nevertheless, the Open Educational resource can provide online video materials on practical issues, as well as scientific research on particular topics can be compiled into a single platform, for instance, the scientific research on papillae patterns and their essential role in identification of a person [Laal A. \& Zile A., 2020]. Those researches can be provided according to the programmes of particular forensic expert examination requirements provided by national laws and regulations.

Understanding the scale of the problem of training for expert institutions and the public demand for qualified experts, we believe that the change in approaches to learning will fill the gap in the implementation of educational activities by higher education institutions and research institutions.

We suppose that the ways to solve this problem should include the use of new forms of learning and training of forensic experts - the Open Educational Resources.

We are convinced that the creation of a thematic resource dedicated exclusively to Forensic Science will fill the educational process with clarity and specificity, which, in turn, will facilitate easy acquaintance with a particular type of Forensic Science and more effective learning.

It should be noted that Open Educational Resources are free, open-licensed educational resources that users can retain, reuse, revise, remix and redistribute for personalised needs (Wiley \& Hilton, 2018).

\section{Conclusion and Implications}

We can state that Open Educational Resources in Ukraine and Latvia are still at the stage of their formation, but the changes of approaches to communication and interaction in the system of education and science is a requirement of time. The first steps to initiate them have been taken, but the issues of implementing this tool in the curricula of higher law education institutions and during the training of professionals in obtaining an expert specialty in expert institutions remain unresolved. There are very few studies on the creation of thematic Open Educational Resources that cover current issues of Forensic 
Science and Criminalistics.

The legislation of Ukraine and Latvia only indirectly regulates the use of Open Educational Resources in higher education institutions and expert institutions. Trends in the development of this industry indicate the need to develop original scientific solutions. It is our deep conviction that the "Open Educational Resource: Forensic Examination" project is directly aimed at developing and promoting Forensic Science and Criminalistics at the international level.

Modern experts must consider new technology as a source of enormous opportunities for development. However, to reap the benefits of such opportunities the future experts need to master a new level of literacy in this digitalised world. The main task of higher education institutions and expert institutions is to quickly adapt to these conditions and offer the educational content that can meet the needs of the European labour market.

\section{Acknowledgement}

This research is funded by the Latvian-Ukrainian Joint Programme of Scientific and Technological Cooperation Project, (2021). "Open Educational Resource: Forensic Science" Project Nr. LV-UA/2021/3.

\section{References}

Atkins D. E., Brown J. S., \& Hammond A. L. (2007). A Review of the Open Educational Resources (OER) Movement: Achievements, Challenges, and New Opportunities. Retrieved from: https://hewlett.org/wp-content/uploads/2016/08/ReviewoftheOERMovement.pdf Accessed 22.03.2021.

Massive open online course. Coursera (2012). Your way to success. Develop skills through online courses, certifications and degree programs from the world's best universities and companies. Retrieved from: https://www.coursera.org/ Accessed 22.03.2021.

Toru Iiyoshi, Vijay Kumar M. S., Brown J. S. (2008). Opening Up Education. The Collective Advancement of Education through Open Technology, Open Content, and Open Knowledge. The MIT Press Cambridge, Massachusetts London, England. ISBN-0-2620-3371-2ISBN-978-0-2620-3371-8.

Wiley D., (2016). The Current State of OER. Organization for Economic Co-operation and Development Centre for Educational Research and Innovation Expert Meeting on Open Educational Resources. Retrieved from: https://www.hewlett.org/wp-content/uploads/2016/08/HistoryofOER.pdf Accessed 22.03.2021.

Massive open online course. EDX (2012). Courses by Subject. Retrieved from: https://www.edx.org/ Accessed 22.03.2021.

Electronic Kyiv-Mohyla Academy Institutional Repository (2002). Policy of the Kyiv-Mohyla Academy National University Institutional Repository. Retrieved from: http://ekmair.ukma.edu.ua/ Accessed 22.03.2021.

Open Access repository of Ternopil National Technical University Ivan Pulyuya (Elartu) (2008). ELARTU Institutional repository of Ternopil National Technical University Ivan Pulyuya. Retrieved from: http://elartu.tntu.edu.ua/ Accessed 22.03.2021.

Electronic Sumy State University Institutional Repository (eSSUIR) (2002). SumDU Repository.

Retrieved from: https://essuir.sumdu.edu.ua/about Accessed 22.03.2021.

Electronic Library of Ukraine: Establishment of Centers of Knowledge in Universities of Ukraine. Access to global digital information (ELibUkr) (2009). ELibUkr: Collaboration for the Future of Ukraine. Retrieved from: http://www.elibukr.org/index.php/uk/ Accessed 22.03.2021. 
Fengchun M., Sanjaya M., McGreal R., (2016). Open educational resources: policy, costs, transformation (UNESCO). ISBN 978-1-894975-75-9. Retrieved from: http://oasis.col.org/bitstream/handle/11599/2306/2016 Perspectives-OER-PolicyTransformation-Costs.pdf?sequence $=1$ \&is Allowed $=\mathrm{y}$ Accessed 22.03.2021.

Geser G., (2012). Open Educational Practices and Resources: OLCOS Roadmap 2012. ISBN 3-902448-08-3. Retrieved from: https://www.olcos.org/cms/upload/docs/olcos roadmap.pdf Accessed 22.03.2021.

Kliuiev, O. ., Agapova, O. ., \& Palkova, K. . (2020). International projects as a new form of collaboration in the sphere of expert ensuring of justice. Archives of Criminology and Forensic Sciences, 2, 24-32. https://doi.org/10.32353/ACFS.2.2020.01

Kumar, G., Saha, R., Lal, C., \& Conti, M. (2021). Internet-of-forensic (IoF): A blockchain based digital forensics framework for IoT applications. Future Generation Computer Systems, 120, 13-25. doi:10.1016/j.future.2021.02.016

Latvian-Ukrainian Joint Programme of Scientific and Technological Cooperation Project, (2021). "Open Educational Resource: Forensic Science" Project Nr. LV-UA/2021/3. Retrieved from: https://viaa.gov.lv/lat/zinatnes inovacijas progr/lv ukrainas sadarbiba/lv ukr projekti/ Accessed 22.03.2021.

Lall A., Zile., A. (2020), Phenomenon of Genesis of Papillae Pattern Prints on Human Skin. SOCRATES. Rịga Stradiņš University Faculty of Law Electronic Scientific Journal of Law Socrates., 3 (18), https://doi.org/10.25143/socr.18.2020.3.049-058.

Law On Forensic Experts. Publication: Latvijas Vēstnesis, 42, 01.03.2016. OP number: 2016/42.1. Retrieved from: https://likumi.lv/ta/en/en/id/280576. Accessed 22.03.2021.

Latvian Register of Forensic experts (2021), Retrieved from: https://eksperti.ta.gov.lv/en/person/search?type=advanced Accessed 22.05.2021.

Leimanis, A. ., \& Palkova, K. (2021). Ethical Guidelines for Artificial Intelligence in Healthcare from the Sustainable Development Perspective. European Journal of Sustainable Development, 10(1), 90. https://doi.org/10.14207/ejsd.2021.v10n1p90

McSherry, C. (2001). Who Owns Academic Work?: Battling for Control of Intellectual Property. Cambridge, MA: Harvard University Press. ISBN: 0-674-00629-1.

The Network for Computational Nanotechnology (Nanohub) (2002). Serving Students, Researchers \& Instructors. Retrieved from: https://nanohub.org/ Accessed 22.03.2021.

Public digital library of open educational resources (2007). OER Commons. Explore. Create. Collaborate. Retrieved from: https://www.oercommons.org/ Accessed 22.03.2021.

Procedures for the Certification and Recertification of Forensic Experts. Cabinet of Ministers: Latvijas Vēstnesis, 251, 23.12.2016. OP number: 2016/251.16. Retrieved from: https://likumi.lv/ta/en/en/id/287605 Accessed 22.03.2021.

Massive open online course. Prometheus project. (2014). The best online courses Ukraine and the world. Retrieved from: https://prometheus.org.ua/ Accessed 10.03.2021.

Ministerstvo Justicii Ukraini (2021). Retrieved from: https://minjust.gov.ua/m/informatsiya-schododiyalnosti-sudovih-ekspertiv-yaki-ne-e-pratsivnikami-derjavnih-spetsializovanih-ustanov-za-2020rik-stanom-na-14042020 Accessed 22.03.2021.

Pro osvitu. Zakon Ukrainy. Verkhovna Rada of Ukraine № 2145-VIII, 05.09.2017. Retrieved from: https://zakon.rada.gov.ua/laws/show/2145-19\#Text Accessed 22.03.2021.

Pro skhvalennia Stratehii rozvytku informatsiinoho suspilstva v Ukraini. Rozporiadzhennia Kabinetu Ministriv Ukrainy № 386-p, 15.05.2013. Retrieved from: https://zakon.rada.gov.ua/laws/show/386-2013\%D1\%80\#Text Accessed 22.03.2021.

Pro zatverdzhennia Polozhennia pro Tsentralnu ekspertno-kvalifikatsiinu komisiiu pry Ministerstvi yustytsii Ukrainy ta atestatsiiu sudovykh ekspertiv. Nakaz Ministerstva yustytsii Ukrainy №301/5, 03.03.2015 Retrieved from: https://zakon.rada.gov.ua/laws/show/z0249-15\#Text Accessed 22.03.2021.

Sandanayake, T.C., Karunanayaka, S.P. \& Madurapperuma, A.P. (2021) A framework to design open educational resources-integrated online courses for undergraduate learning: A design-based research approach. Educ Inf Technol https://doi.org/10.1007/s10639-020-10393-z

Transforming our world: the 2030 Agenda for Sustainable Development. Resolution adopted by the General Assembly on 25 September 2015. Retrieved from: https://www.un.org/ga/search/view doc.asp ? symbol=A/RES/70/1\&Lang $=$ E Accessed 22.03.2021. 
Tang, H. (2020). Implementing open educational resources in digital education. Education Tech Research Dev. https://doi.org/10.1007/s11423-020-09879-x

World Summit (2005). Building the Information Society: a global challenge in the new Millennium. Declaration of Principle. World Summit on the information Society, Geneva. Retrieved from: https://www.itu.int/dms pub/itu-s/md/03/wsis/doc/S03-WSIS-DOC-0004!!PDF-E.pdf Accessed 22.03.2021.

Wiley, D.A. (2020) Open educational resources: undertheorized research and untapped potential. Education Tech Research Dev. Retrieved from https://doi.org/10.1007/s11423-020-09907-w. Accessed 19.03.2021. 